ORNL/TM-2000/1

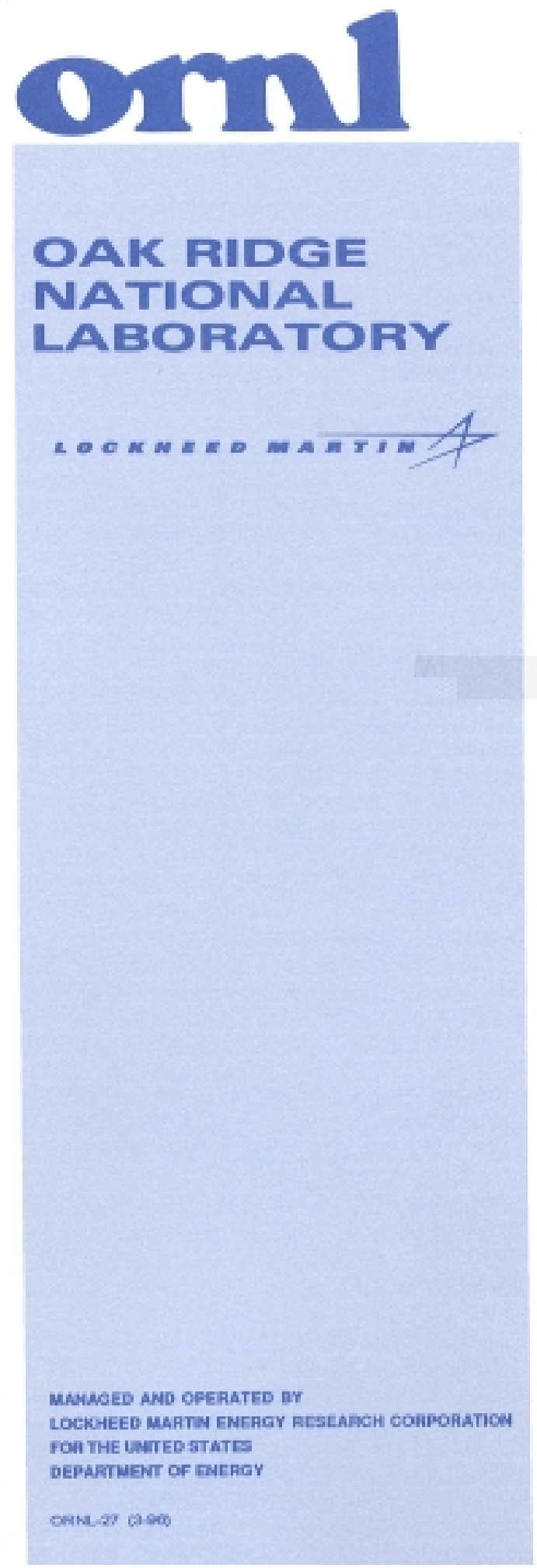

\title{
Analysis of the Radiation Fallout Tests at ETBS, France (Fall 1996)
}

J. M. Barnes

R. T. Santoro 
This report has been reproduced directly from the best available copy.

Available to DOE and DOE contractors from the Office of Scientific and Technical Information, P.O. Box 62, Oak Ridge, TN 37831; prices available from (865) 576-8401.

Available to the public from the National Technical Information Service, U.S. Department of Commerce, 5285 Port Royal Rd., Springfield, VA 22161.

This report was prepared as an account of work sponsored by an agency of the United States Government. Neither the United States nor any agency thereof, nor any of their employees, makes any warranty, express or implied, or assumes any legal liability or responsibility for the accuracy, completeness, or usefulness of any information, apparatus, product, or process disclosed, or represents that its use would not infringe privately owned rights. Reference herein to any specific commercial product, process, or service by trade name, trademark, manufacturer, or otherwise, does not necessarily constitute or imply its endorsement, recommendation, or favoring by the United States Government or any agency thereof. The views and opinions of authors expressed herein do not necessarily state or reflect those of the United States Government or any agency thereof. 


\title{
ANALYSIS OF THE RADIATION FALLOUT TESTS AT ETBS, FRANCE (FALL 1996)
}

J. M. Barnes

R. T. Santoro

Date published: January 2000

\author{
Prepared by the \\ Oak Ridge National Laboratory \\ Oak Ridge, TN 37831-6363 \\ Managed by \\ Lockheed Martin Energy Research Corp. \\ for the \\ U.S. Department of Energy \\ under contract DE-AC05-96OR22464
}





\section{CONTENTS}

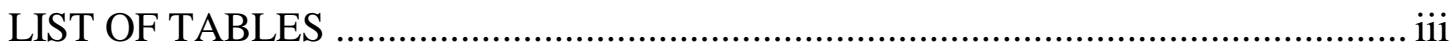

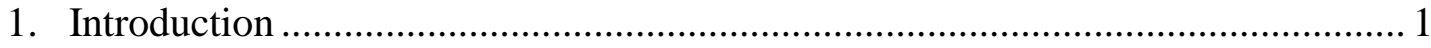

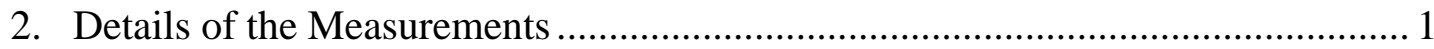

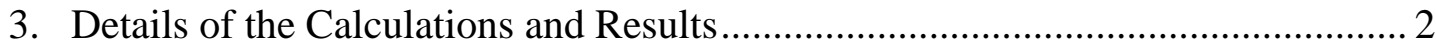

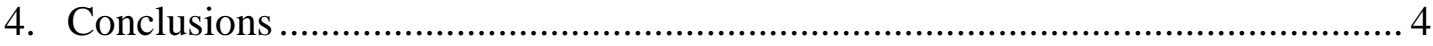

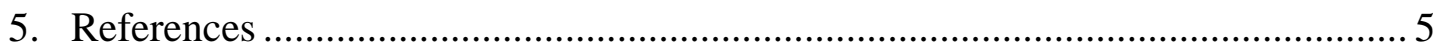

\section{LIST OF TABLES}

Table 1. Decay Gamma-Ray Emission Spectrum from ${ }^{140} \mathrm{La}$............................. 1

Table 2. Composition of Materials Used in the DORT Calculation ....................... 2

Table 3. Comparison of Measured and Calculated Free-Field Dose Rates.............. 3

Table 4. Protection Factors for the Iron Cylinders ........................................... 3

Table 5. Protection Factors for the T72M Tank ...................................................... 4 

ORNL/TM-2000/1

\title{
Analysis of the Radiation Fallout Tests at ETBS, France (Fall 1996)
}

\author{
J. M. Barnes and R. T. Santoro \\ Oak Ridge National Laboratory
}

\begin{abstract}

\section{Introduction}

A series of experiments were carried out at the Etablissement Technique de Bourges (ETBS), France to measure protection factors for the Russian T72M tank during exposure to gamma radiation emanating from the ground ${ }^{(1)}$. The purpose of these measurements was to determine the reduction in the dose rate to the tank occupants when the vehicle traverses terrain that has been contaminated as the result of fallout from a nuclear weapon or when the ground has been contaminated by the distribution of radioactive material by terrorists.
\end{abstract}

This report summarizes results of calculations that replicate the measurements. Comparisons of measured and calculated protection factors are reported for a series of nested iron cylinders and the T72M tank. The cylinder measurements were performed to compare protection factors measured at Bourges with those obtained previously at the US Army Aberdeen Test Center ${ }^{(2)}$.

\section{Details of the Measurements}

Measurements were carried out on an $80 \mathrm{~m} \times 80 \mathrm{~m}$ field at the Terrain d'appendage site at ETBS. To simulate fallout, the field was sprayed with ${ }^{140} \mathrm{La}\left(\mathrm{T}_{1 / 2}=40.27 \mathrm{~h}\right)$. The decay gamma-ray spectrum from ${ }^{140} \mathrm{La}$ is given in Table 1 . The radioisotope was in the form of $(\mathrm{La})_{2} \mathrm{CO}_{3}$ suspended in water. The field was sprayed on two occasions (29 Oct $1996-$ $12.5 \mathrm{MBq} / \mathrm{m}^{2}$ and $4 \mathrm{Nov} 1996-19.0 \mathrm{MBq} / \mathrm{m}^{2}$ ) to yield a net activity level of 20.1 $\mathrm{MBq} / \mathrm{m}^{2}$ (corrected to 0800 hours 4 Nov 1996). The net activity is less that the sum due to decay of the radioisotope.

Table 1. Decay Gamma-Ray Emission Spectrum from ${ }^{140} \mathrm{La}$

\begin{tabular}{cc}
\hline \hline Energy $(\mathrm{MeV})$ & Emission Rate (\%) \\
\hline 1.596 & 95.40 \\
0.487 & 45.90 \\
0.816 & 23.64 \\
0.329 & 20.74 \\
\hline \hline
\end{tabular}

Lanthanum was selected to simulate the fallout field since it has an average gamma-ray energy that is similar to that of ${ }^{60} \mathrm{Co}$ which was used in earlier tests at the US Army 
Aberdeen Test Center ${ }^{(2)}$. The advantage of using ${ }^{140} \mathrm{La}$ is that the half-life is long enough to perform the measurements and short enough so there is no trace of activity in the soil after $\sim 1$ month.

Free-field measurements were made at the center of the field using a 5.08-cm x $5.08-\mathrm{cm}$ $\mathrm{NaI}$ detector and a Philips Model No. Zp1220 GM counter each placed at $1 \mathrm{~m}$ above the ground. The measured free-field dose rate at the center of the field taking into account corrections for ${ }^{140} \mathrm{La}$ decay was $10.91 \mathrm{mrem} / \mathrm{h}$.

Measurements of the protection factors for the nested iron cylinders and the T72M tank were also made at the center of the irradiated field.

\section{Details of the Calculations and Results}

The calculated results were obtained using the MASH v2.0 Code System ${ }^{(3)}$. The two dimensional discrete ordinates code DORT was used to calculate the gamma ray fluence on a coupling surface surrounding the test assemblies. The Adjoint Monte Carlo methods was then used to estimate the dose rate importance of the surface fluence. A processing code folded the fluence with the dose rate importance and generated the desired responses and protection factors.

The DORT calculations were run in R-Z geometry with the $80-\mathrm{m} \times 80-\mathrm{m}$ field being modeled as a 40-m-radius surface. The ${ }^{140} \mathrm{La}$ source was distributed in the soil in a $0.3-$ $\mathrm{cm}$-thick layer to account for the penetration of the sprayed liquid into the soil. Sensitivity calculations were performed to compare the free-field dose rate at the center of the field as a function of the source layer thickness. The 40-m-radius surface was divided into 27 radial intervals each with an average source strength of $20.1 \mathrm{MBq} / \mathrm{m}^{2}$. The air above the soil layer was modeled using 87 intervals extending to $2000 \mathrm{~m}$.

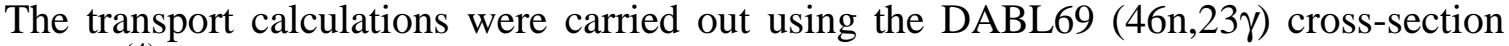
library ${ }^{(4)}$. The compositions of the air and soil used in the DORT calculations are given in Table 2. Also included in the table is the composition of the iron used in the analysis of the nested cylinder measurements.

Table 2. Composition of Materials Used in the DORT Calculation

\begin{tabular}{cccc}
\hline \hline Element & Air & Ground & Iron Cylinders \\
\hline \multicolumn{4}{c}{ Atomic Density $\left(\mathrm{cm}^{-3}\right)$} \\
$\mathrm{H}$ & $9.57 \times 10^{-3}$ & \\
$\mathrm{C}$ & & $7.82 \times 10^{-4}$ \\
$\mathrm{O}$ & $4.19 \times 10^{-5}$ & & \\
$\mathrm{Al}$ & $1.13 \times 10^{-5}$ & $3.48 \times 10^{-2}$ & \\
$\mathrm{Si}$ & & $4.88 \times 10^{-3}$ & \\
$\mathrm{Ar}$ & & $1.16 \times 10^{-2}$ & \\
$\mathrm{Mn}$ & $2.51 \times 10^{-7}$ & & $3.88 \times 10^{-4}$ \\
$\mathrm{Fe}$ & & & $8.40 \times 10^{-2}$ \\
\hline \hline
\end{tabular}


The experimentalists did not provide information about the meteorological or soil conditions at the time of the measurements. The air composition corresponds to that at standard temperature and pressure and with no water vapor. The ground is assumed to be dry.

A 226-direction quadrature set with a minimum polar angle cosine of 0.00544 and a lineof-sight distance of $183.8 \mathrm{~m}$ for calculation of the uncollided flux was adopted here. The use of this quadrature set for fallout field and radiological threat analyses was previously determined by Johnson, Santoro and Smith ${ }^{(5)}$ to be optimum for this kind of application.

Free-field dose rates measured and calculated at $1.0 \mathrm{~m}$ above the ground surface are summarized in Table 3. The measured and calculated data agree within $3 \%$.

Table 3. Comparison of Measured and Calculated Free-Field Dose Rates

\begin{tabular}{cc}
\hline \hline \multicolumn{2}{c}{$\begin{array}{c}\text { Free Field Dose } \\
(\mathrm{mrem} / \mathrm{h})\end{array}$} \\
\hline Measured & 10.91 \\
Calculated & 10.60 \\
$\mathrm{C} / \mathrm{M}$ & 0.97 \\
\hline \hline
\end{tabular}

\section{Iron Cylinder Protection Factors}

The iron cylinders are $75 \mathrm{~cm}$ high with a maximum outer dimension of $100 \mathrm{~cm}$. Iron plates were used to close the top and bottom of the cylinders. During the measurements, the cylinders were placed on a steel frame that was $75 \mathrm{~cm}$ long by $75 \mathrm{~cm}$ wide and $50 \mathrm{~cm}$ high. The detectors (NaI and GM) were placed inside the can at $100 \mathrm{~cm}$ above the ground corresponding to the same height used for the free-field measurements. A nested cylinder configuration was used to vary the wall thickness. Four cylinder configurations were studied: 10-10-10, 6-6-6, 2-6-6, and 2-2-2. The notation indicates the thickness of the top plate, wall and base plate.

The calculated protection factors for the four cylinder configurations are compared with measured values in Table 4 . The calculated protection factors vary by as much as $23 \%$ with the $\mathrm{NaI}$ data and by as much as $46 \%$ with the GM measurements. The NaI detector measurements yield higher protection factors than the GM counter. This trend was also observed in the measurements for the T72M tank discussed below.

Table 4. Protection Factors for the Iron Cylinders

\begin{tabular}{cccccc}
\hline \hline Configuration & NaI & GM & Calculated & C/NaI & C/GM \\
\hline $10-10-10$ & 26 & 21.9 & 32 & 1.23 & 1.46 \\
$6-6-6$ & 7.1 & 6.2 & 7.1 & 1.00 & 1.15 \\
$2-6-6$ & 5.7 & 4.8 & 6.6 & 1.16 & 1.38 \\
$2-2-2$ & 2.2 & 2.1 & 1.8 & 0.82 & 0.86 \\
\hline \hline
\end{tabular}




\section{T72M Tank Protection Factors}

Protection factors for the commander and driver of the T72M tank were calculated for the case when the tank is at the center of the activated field. The tank geometry and composition was provided by the National Ground Intelligence Center. Protection factors for the commander and gunner's head locations were calculated for the condition with the vehicle hatches closed. Measurements were made at other crew locations with the tank hatch open. Since the intention of this analysis was to demonstrate that the MASH code system is applicable for determining protection factors for a simulated fallout field and because the code running times for the complex T72M geometry are long, the comparisons given here are sufficient.

The measured and calculated protection factors for the commander and driver's head locations are compared in Table 5. Tissue dose rates were calculated at the actual locations of the two head positions. These were both higher above the ground than the height at which the free field dose rate was measured. The measured and calculated protection factors were determined from the ratio of the dose rate at the head locations divided by the free-field dose rate at $1 \mathrm{~m}$.

Table 5. Protection Factors for the T72M Tank

\begin{tabular}{cccccc}
\hline \hline Configuration & NaI & Calculated & GM & C/NaI & C/GM \\
\hline & \multicolumn{5}{c}{ Hatch Closed } \\
Commander's Head & 49.1 & 47.3 & 35.50 & 0.96 & 1.33 \\
Gunner's Head & 50.1 & 42.5 & 42.80 & 0.85 & 0.99 \\
\hline \hline
\end{tabular}

The calculated protection factors are in good agreement with the NaI measurements at the commander's head location and differs by $15 \%$ at the gunner's head. The agreement with the GM measurements is $33 \%$ high at the commander's location and in good agreement at the gunner location. As for the iron cylinder measurements, the $\mathrm{NaI}$ results are higher than the GM data.

\section{Conclusions}

The potential of the MASH Code System in estimating protection factors for a radiological source on the surface of the ground was demonstrated in Ref. 5. The results obtained in this work benchmark the calculational results with measured data. The ratios of the calculated and measured data are quite acceptable and comparable with the differences between the NaI and GM results.

Different protection factors are reported for the NaI and GM measurements in most of the experiments reported in Ref. 1. While these authors believe the NaI results to be more reliable, the experimentalists should resolve the disparity between the $\mathrm{NaI}$ and GM data. 


\section{References}

1. C. R. Heimbach, M. A. Oliver, and M. B. Stanka, "Research Project of the Radiation Fallout Tests at Etablissement Technique de Bourges (fall 1996), TECOM Project No. 20CO-430-APR-156, Report No. ATC-8103 (Sep. 1998)

2. C. R. Heimbach, M. A. Oliver, and M. B. Stanka, "Research Project of the Radiation Fallout Tests at Etablissement Technique de Bourges (fall 1996), Report No. ATC8071 (Apr. 1998)

3. J. O. Johnson, ed., “A User's Manual for MASH v.2.0 - A Monte Carlo Adjoint Shielding Code System", ORNL/TM-11778/R2, Oak Ridge National Laboratory, (1999)

4. D. T. Ingersoll, R. W. Roussin, C. Y. Y. Fu, J. E. White, "DABL69: A Broad Group Neutron/Photon Cross-Section Library for Defense Nuclear Applications", ORNL/TM-10568, Oak Ridge National Laboratory, (1989)

5. J. O. Johnson, R. T. Santoro and M. S. Smith, " Application of the MASH 1.0 Code System to Radiological Warfare Threats", ORNL/TM-12328, Oak Ridge National Laboratory (October 1993) 



\section{INTERNAL DISTRIBUTION}

1. Y. Y. Azmy

2. J. M. Barnes

3. D. T. Ingersoll

4. J. O. Johnson

5. M. A. Kuliasha

6. R. A. Lillie

7. R. H. Morris

8. J. V. Pace III
9. R. T. Santoro

10. C. O. Slater

11. D. B. Simpson

12. J. J. Yugo

13. Laboratory Records (for submission to OSTI)

14. Laboratory Records-RC

15. ORNL Central Research Library

\section{EXTERNAL DISTRIBUTION}

16. Dr. Craig Heimbach, Radiation Team Survivability/Lethality, U.S. Army Aberdeen Test Center, Aberdeen Proving Ground, MD 21005-5059

17. Mr. Robert Kehlet, Defense Threat Reduction Agency, 6801 Telegraph Road, Alexandria, VA 22310

18. Major M. Lewis, Commander, National Ground Intelligence Center, 220 Seventh Street, N.E., Charlottesville, VA 22901-5396

19. Mr. Thaddeus Lewis, Commander, National Ground Intelligence Center, 220 Seventh Street, N.E., Charlottesville, VA 22901-5396 